\title{
Forest Fire Risk Mapping by using GIS Techniques and AHP Method: A Case Study in Bodrum (Turkey)
}

\author{
Abdullah E. Akay* (i), Halil Şahin \\ Bursa Technical University, Faculty of Forestry, 16310 Bursa, Turkey
}

\begin{abstract}
In Turkey, forest areas located along the coastline of the Marmara, the Aegean and the Mediterranean regions are very sensitive to fire. As a result of forest fires, about 10000 hectares of forest area is damaged annually. One of the key elements in firefighting is early detection and quick intervention. In order to achieve this goal, first of all, the forest areas with fire risk should be determined especially for fire sensitive forest areas. The forest fire risk can be evaluated considering various risk factors such as stand structures, topographic factors, proximity to some features (roads, settlements, and water resources), and climatic factors. In this study, GIS techniques and Analytic Hierarchy Process (AHP) method was used to produce forest fire risk map for the first degree fire sensitive forest land located in Bodrum province of Muğla in Turkey. The results indicated that $11.83 \%$ and $21.98 \%$ of the forest area was categorized as very high and high fire risk, respectively, while $22.28 \%$ and $25.93 \%$ was moderate and low fire risk, respectively. The fire risk was found to be very low at the rest of the study area (17.98\%). To compare the fire risk map with actual forest fire occurrences in the study area, it was overlapped with the fire map indicating forest components where previous forest fires (>1.0 ha) occurred in the study area in last five years. It was found that $38.32 \%$ of the areas damaged by the previous fires were categorized as high and very high fire risks zones in fire risk map, while $28.44 \%$ was moderate fire risk zones. The result showed that tree species was the most effective risk factor, followed by tree stages and proximity to water resources. This study revealed that the combination of GIS techniques and AHP method is very advantageous approach to map forest areas with fire risk in short time.
\end{abstract}

Keywords: Forest fire, GIS, Fire risk map, AHP, Turkey

\section{Introduction}

In the last decades, the high population growth rate and increased public demands on forest products have increased the pressure on forest resources which are considered as one of the important renewable natural resources. The most apparent reflections of this pressure on forest resources are openings in forest areas, illegal cutting, and forest fires (Ertuğrul, 2005). Forest fires cause severe damages on forest ecosystem which leads to biological and ecological impacts on forest vegetation (Bilici, 2009). Besides, the economic value of firedamaged trees are greatly reduced and they become more vulnerable to insects and fungus after fire incidents (Akay et al., 2007). The sustainability of forest resources are seriously affected by forest fires particularly in arid regions covered with fire sensitive trees (Demir et al., 2009). In Turkey, about 5.5 million hectares of forest lands along the shoreline from Mediterranean to Marmara Region are the first degree fire sensitive areas (Akay and Erdoğan, 2017). According to the fire statistics, the cities of Antalya (2013 ha), İzmir (799 ha), Muğla (769 ha), and Balıkesir (657 ha) are in the top five in terms of average annual forest land damaged by forest fires (GDF, 2016).

Forest fire risk varies depending on risk factors such as stand structures, topographic factors, proximity to some features, and climatic parameters (Carmel et al., 2009). The tree species, crown closure, and tree stage are main vegetation structures that affect fire ignition (Gao et al., 2011). Regarding forest fires, tree species appear to be one of the most important factors affecting the risk of fire. Coniferous trees with low-moisture and highly flammable resin are risky species in terms of forest fire due to their rapid ignition potentials. On the other hand, deciduous species with high moisture content show resistance to forest fire as they ignite late (Gazzard, 2012). The crown closure is also critical for forest fire, especially in stands with crown closure of $70 \%$ and over. Due to high density of easily igniting fine matter, forest fires are rapidly transformed from surface fire to into crown fire and spread more rapidly (Küçük et al., 2009). In forests with low crown closures, forest fires generally continue as surface fires which can be extinguished in a short time. Tree stage is another stand structure that has 
a close relationship with fire risk. The fire risk is high at young stages, while risk decreases from the mature to over mature stages (Bilgili, 2003; Sağlam et al., 2008).

Ground slope and aspect are main topographic features that influence the forest fire risk (Erten et al., 2004). Fire moves most rapidly up slopes when other risk factors are considered to be constant. Besides, increasing ground slope increases the forest fire risk (Jaiswal et al., 2002). Fire risk also vary depending on the aspect as a function of temperature and humidity. The fire risk is relatively high in south aspects because of low humidity (Lin and Sergio, 2009). Climatic factors such as temperature, precipitation, and wind are effective on forest fire risks. If the air temperature is high, flammable materials heat up, reach the ignition temperature easily and forest fires spread more rapidly (Çanakçığlu, 1993). Precipitation directly affects the moisture content of the flammable material, thus, dry winter or spring period makes the summer period more risky in terms of forest fires. Winds carry heat and gases released during forest fires to unburned flammable materials (Küçük et al., 2009). Strong winds move flames to further distances, cause fires to jump between tree tops, spread fires quickly by firing sparks in the front line, and also increase the burning area depending on its speed (Çanakçıŏglu, 1993).

Forest areas located near road networks and settlements are more susceptible to fire as possibilities of accidental and man-made fires increase in these areas. Human activities along the road network and around the residential areas potentially increase; therefore, forests with close proximity to roads and settlements are more prone to fire (Jaiswal et al., 2002). The distance to water resources is another factor that play important role in forest fire risk. In forest areas close to the water resources, the fire can be controlled in a short time, while the firefighting activities are adversely affected in the remote areas (Çanakçıŏlu, 1993).

To minimize the ecological and economic impacts of forest fires, spatial patterns of fire risk zones should be determined and precaution actions must be taken against forest fires in risky areas (Akay and Erdoğan, 2017). For an accurate assessment of forest fire risk zones, fire risk maps are produced using data layers representing fire risk factors (Jaiswal et al., 2002). GIS techniques have significant potentials in generation of fire risk maps by providing fire managers with great opportunity to evaluate various data layers belonging to large areas in a short time (Erten et al., 2005). Basaran et al. (2007) generated fire risk map for Forestry Regional Directorate of Antalya in Turkey by using meteorological data along with chronological fire data from previous years. As a result of the study, it was reported that the coastline of Antalya region has high forest fire risk. In a similar study conducted by Özelkan (2008), a fire risk map was produced for the mountainous areas where forest fire intervention is very difficult due to surface shapes and terrain structure. The fire risk map was generated by using 3D analysis and NDVI (Normalized Difference Vegetation Index) methods based on specified risk factors including vegetation, topography, and distance to the roads and settlements.

In recent years, GIS techniques have been integrated with Multi-Criteria Decision Analysis (MCDA) to provide quick and effective method for fire risk mapping (Carmel et al., 2009). Analytical Hierarchy Process (AHP) is one of the most common MCDA methods used to solve complex spatial problems in the field of forestry (Gülci, 2014). Özşahin (2014) conducted a forest fire sensitivity analysis for Antakya Forest Enterprise Directorate (FED) in Turkey. In the solution process, the factors affecting forest fire risk and the factors affecting the fire response were analyzed by using GIS techniques and AHS method. The results showed that the presented methodology can be used as a tool for effective decision making in forest fire planning. In a similar study, Akay and Erdoğan (2017) used GIS-based AHP method to generate forest fire risk map for Dursunbey FED which was classified as the first-degree fire sensitive area. They evaluated five risk factors including tree species, crown closure, tree stage, slope and aspect. The results indicated that $23.81 \%$ of the area was under extreme fire risk, while $25.81 \%$ was under high risk.

In this study, GIS techniques and AHP method was used to produce forest fire risk map by considering various fire risk factors including tree species, crown closure, tree stages, slope, aspect, and proximity to roads, settlements, and water resources. The study was implemented in Milas FED which was categorized as the first-degree fire sensitive area.

\section{Material and Methods}

\subsection{Study Area}

The study area was the forest area within the border of Bodrum Forest Enterprise Chief (FEC) located in Milas FED in the city of Muğla in Turkey (Figure 1). The average elevation and ground slope in the FED are about $202 \mathrm{~m}$ and $23 \%$, respectively. The dominant species in the study area are Brutian Pine, Stone pine, and Maquis.

\subsection{GIS Database}

The fire risk map was generated based on GIS database consisted of spatial data layers $\left(\begin{array}{llll}10 & \mathrm{~m} & \mathrm{x} & 10 \mathrm{~m}\end{array}\right)$ representing specified fire risk factors: tree species, crown closure, tree stages, slope, aspect, and proximity to roads, settlements, and water resources. Since climate does not vary significantly in Bodrum FEC, climatic parameters were not included in the study. Data layers of the risk factors were generated based on forest management map (1:25000) and topographic map (1:25000) which were obtained from Milas FED. The information (i.e. date, location, fire damaged area) about forest fires occurred in Bodrum was obtained from Milas FED. Then, the map of the previous fires was generated based on the fire location information. In the study, GIS analysis were performed by using ArcGIS. 


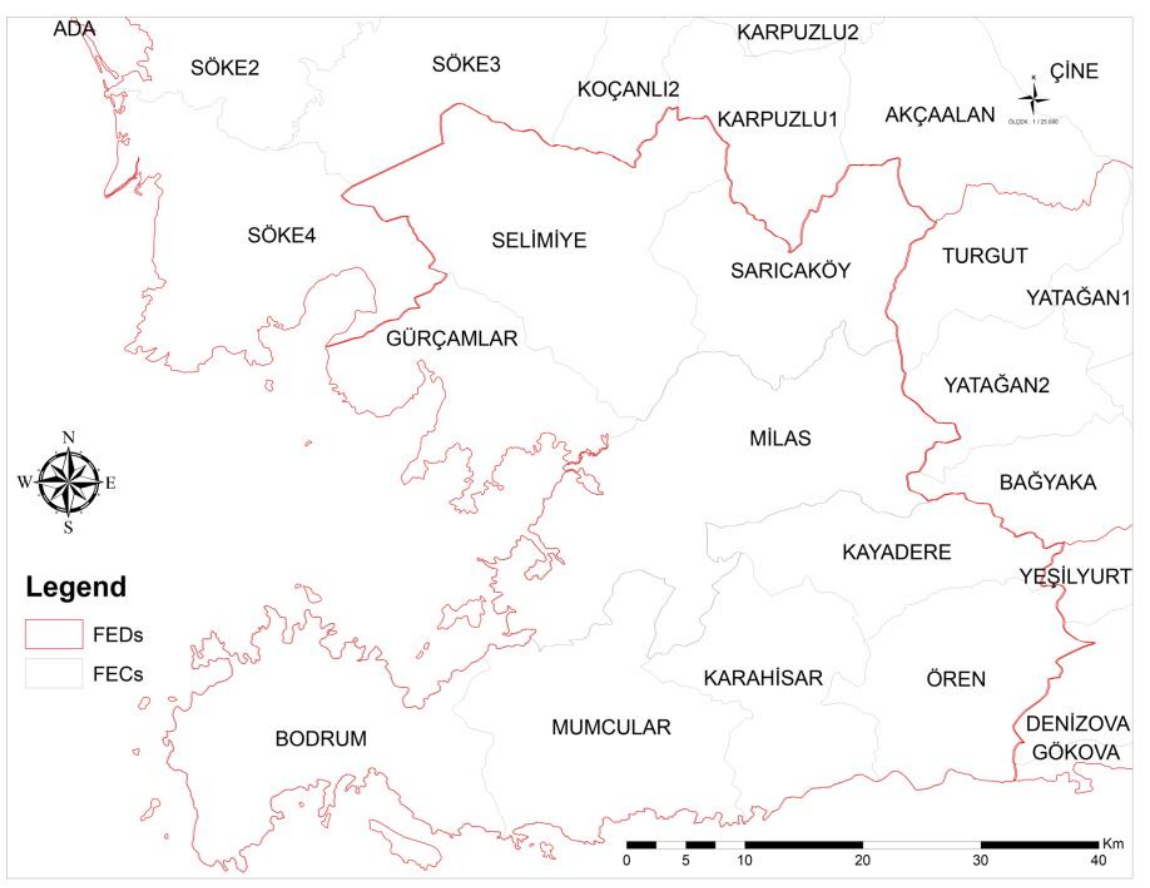

Figure 1. Bodrum FEC in the border of Milas FED

\subsubsection{Stand Structures}

Stand structures that affect fire risk were considered to be tree species, crown closure, and tree stage. Firstly, land use map of Bodrum FEC was generate based on the forest management map. The forest map, as the border of study area, was produced by delineating the forest area from the land use type map. Then, forest map was used to produce data layer for tree species. The crown closure, defined as the proportion of ground area covered by tree crowns, was categorized in four groups; bare-land (0$10 \%)$, sparse $(11-40 \%)$, moderate $(41-70 \%)$, and dense $(>70 \%)$. In the forested areas, the fire risk increases as crown closure increases (Bilgili, 2003). The tree stages were categorized under five groups as indicated in Table 1 . The fire risk is high at early stages, while it decreases at over mature stages (Sağlam et al., 2008).

\begin{tabular}{ll}
\multicolumn{2}{c}{ Table 1. Tree stages } \\
\hline Tree & Average \\
Stages & DBH $(\mathrm{cm})$ \\
\hline Young & $<0-8$ \\
Middle-aged & $8-19.9$ \\
Maturing & $20-35.9$ \\
Mature & $36-51.9$ \\
Over mature & $>52$ \\
\hline
\end{tabular}

\subsubsection{Topographic Features}

In this stage, Digital Elevation Model (DEM) was generated by using the contour lines (with $10 \mathrm{~m}$ intervals) based on topographical map of the study area. Then, the slope and aspect maps were generated based on the DEM. Finally, slope map was reclassified in five classes including gentle (0-5\%), low (5-15\%), medium $(15-25 \%)$, high $(25-35 \%)$, and steep (>35\%). As the ground slope increases, the spreading speed of fire increases, which leads to high fire risk (Jaiswal et al., 2002).

\subsubsection{Proximity to Roads, Settlements, and Water}

The data layers representing road network and settlements were generated based on the topographic map and forest management map, respectively. In order to assign forest fire risk rates for the forest areas considering their proximity to roads, settlements, and water resources, buffer zones were generated around these features by using "Buffer" utility in ArcGIS. Based on the relevant literatures, buffer zones of $100 \mathrm{~m}, 200 \mathrm{~m}$, $300 \mathrm{~m}$, and $400 \mathrm{~m}$ were generated around the road network and settlements data (Sivrikaya et al., 2011). The forest areas near road network and settlements are more prone to fire because human activities can lead to or accidental fire (Jaiswal et al., 2002).

Because fire distinguishing and cooling operations conducted by fire helicopter team is crucial in firefighting activities and their major water resource is mostly sea, Aegean Sea covering the three sides of Bodrum FEC was considered as the water resources in this study. To ensure safe operation during water loading by helicopter at the sea shore, $50 \mathrm{~m}$ of restricted zone was generated along the coast line using "Buffer" analysis. The zone widths were determined based on the helicopter arrival time to fire areas at each turn. Based on the information provided by fire managers, arrival time was classified into four time periods (i.e. 1.5, 2.0, 2.5, and 3.0 minutes) with respect to fire risk. These time periods included helicopter round-trip flight time and additional time spent on maneuvering and water loading activity. The additional time was estimated as one minute based on the experiences of fire managers. 
Finally, buffer zones of 1000 m, 2000 m, 3000 m, and $4000 \mathrm{~m}$ were generated around the restricted zone considering the four time periods and the average speed of the fire helicopter. The average helicopter speed was estimated as $225 \mathrm{~km} /$ hour considering the fire helicopters utilized during the fire season in Turkey (Akay et al., 2012).

\subsection{AHP Method}

The fire risk map was produced by using GIS techniques integrated with AHP method. The AHP method is used to search for the optimal solution among alternative options by evaluating a set of criteria (Alpert, 1968; Saaty, 1977). In this study, the study area was classified into five forest fire risk classes (options) including very low, low, moderate, high, and very high. The main criteria were tree species, crown closure, tree stage, slope, aspect, and proximity to roads, settlements, and water resources. To generate a weight for each criterion decision maker's pairwise comparisons were used and then the relative importance between two criteria was measured based on a numerical scale from 1 to 9 (Table 2).

Table 2. The relative importance values

\begin{tabular}{cl}
\hline ImportanceScale & \\
\hline 1 & Equal importance \\
3 & Weak importance of one over \\
5 & another \\
7 & Essential or strong importance \\
9 & Abmonstrated importance \\
$2,4,6,8$ & Intermediate values between \\
& the two adjacent judgments \\
\hline
\end{tabular}

In the solution process, importance of sub-criteria were evaluated with respect to fire risks. The higher score was given when the criterion was more important. The weighted averages of the sub-criteria, computed using the normalized pairwise comparison matrix, were assigned to the corresponding criteria by using
"Reclassify" tool of ArcGIS. Then, "extAhp 2.0" plugin was used to combine the weighted averages of the criteria.

\section{Results and Discussion \\ 3.1. GIS Data Layers \\ 3.1.1. Stand Structures Data Layers}

It was found that the land use type covering the largest part of the Bodrum FEC was forests (39.39\%) while the second largest was agricultural lands (37.27\%), followed by settlements (12.90\%) (Table 3, Figure 2). In terms of tree species, there were seven species or species compositions in the forest area (Table 4, Figure 3). The most common species was maquis $(41.61 \%)$, followed by Brutian pine $(32.41 \%)$ and degraded species $(25.67 \%)$.

Table 3. The land use types

\begin{tabular}{lc}
\hline $\begin{array}{l}\text { Land Use } \\
\text { Types }\end{array}$ & Area $(\%)$ \\
\hline Forest & 39.390 \\
Agriculture & 37.265 \\
Settlement & 12.900 \\
Forest Soil-Soil & 4.907 \\
Sand & 0.005 \\
Soil & 0.344 \\
Stoniness & 0.094 \\
Forest Soil & 4.731 \\
Swamp & 0.078 \\
Energy Lines & 0.021 \\
Mines & 0.260 \\
Water & 0.004 \\
\hline
\end{tabular}

Table 4. Tree species and species compositions

\begin{tabular}{lc}
\hline Tree Species & Area $(\%)$ \\
Compositions & 32.41 \\
\hline Brutian pine & 41.61 \\
Maquis & 25.67 \\
Degraded species & 0.03 \\
Date palm & 0.03 \\
Brutian pine, Aleppo Pine & 0.25 \\
Aleppo Pine & 0.00 \\
Stone pine & \\
\hline
\end{tabular}

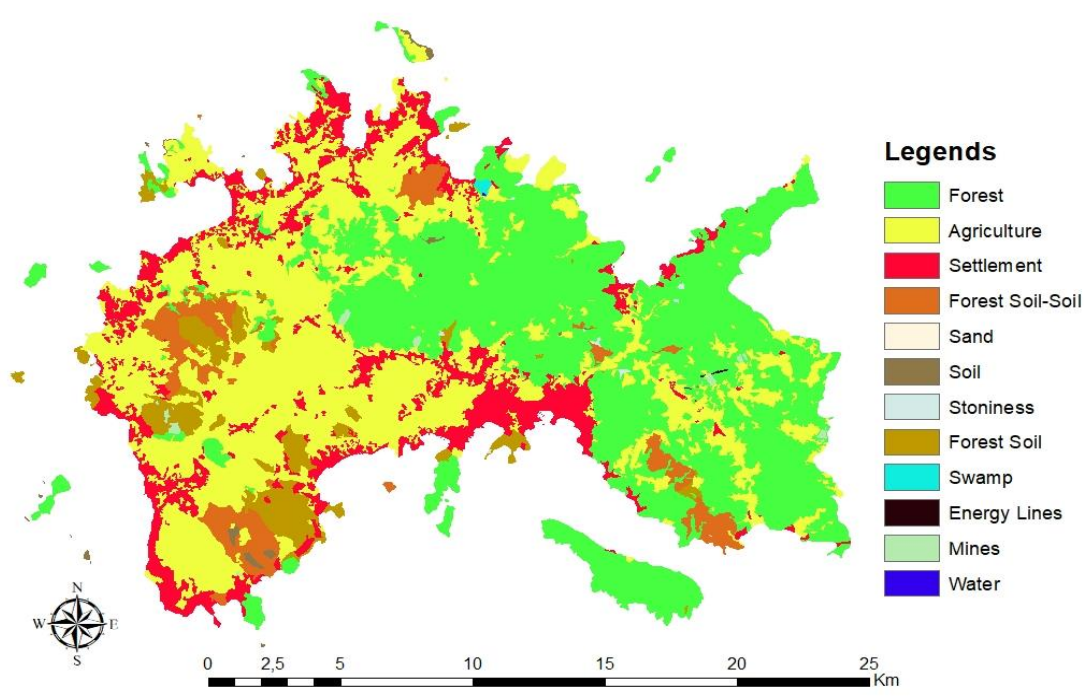

Figure 2. Land use type map 


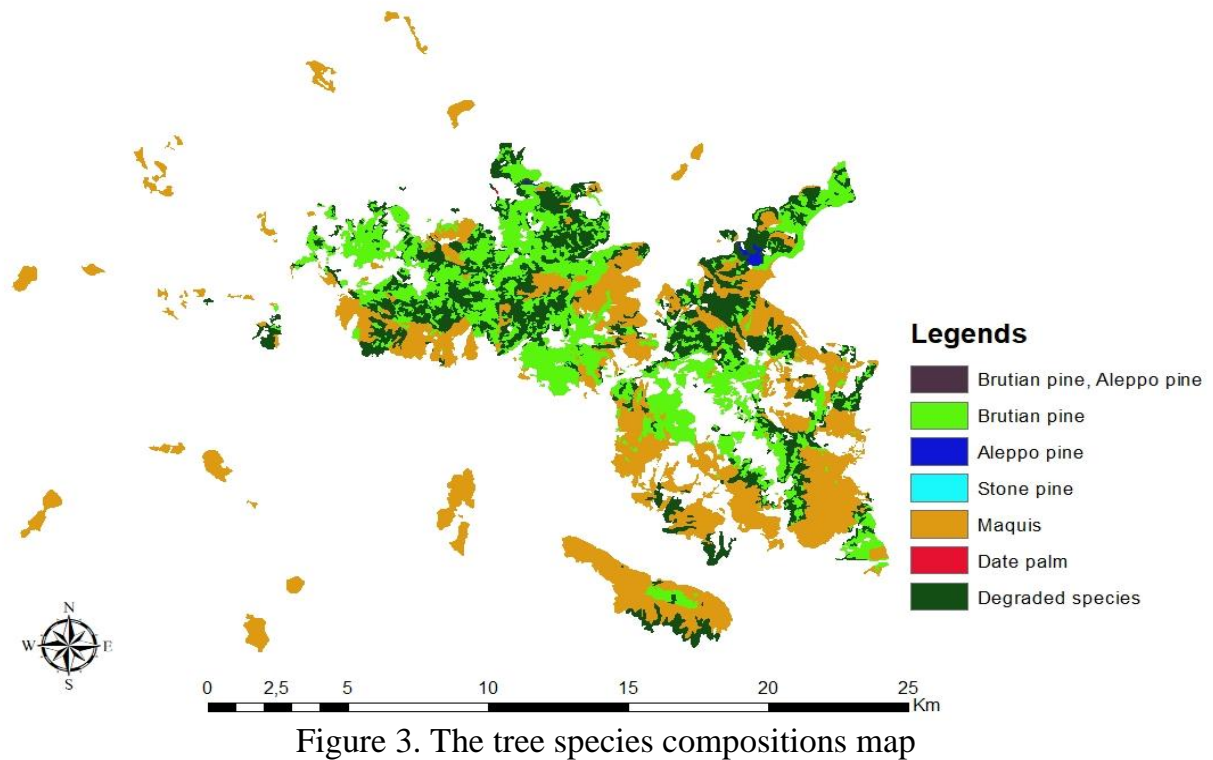

The map of the crown closure factor indicated that closure was $12.31 \%$. The results also indicated that more than half of the study area was bare-land (\%53.12), followed by sparse $(18.35 \%)$ and dense closures $(16.22 \%)$ (Figure 4$)$. The percentages of the moderate $21.50 \%$ and $14.80 \%$ of the study area was covered by young tree stages and maturing stages, respectively (Figure 5).

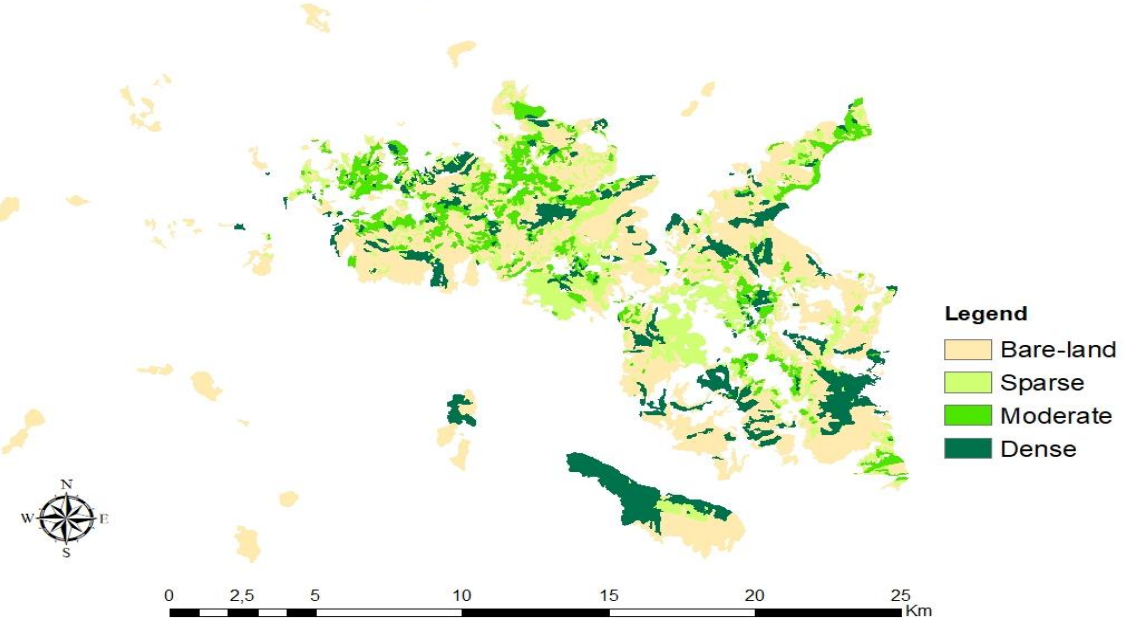

Figure 4 . The map of crown closure

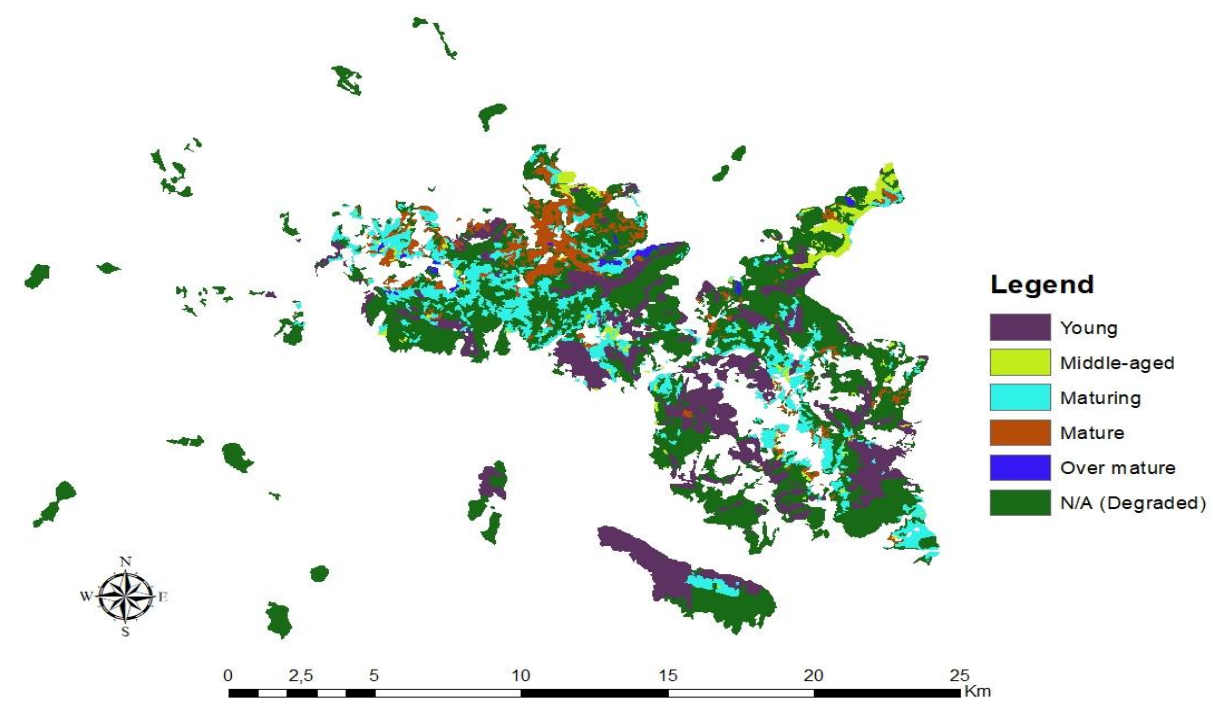

Figure 5. The tree stages map 


\subsubsection{Topographic Features Data Layer}

It was found that $48.82 \%$ of the study area was on steep slope, while $21.60 \%$ was on high slope class (Figure 6). According to literatures, fire risk is very high on forest areas located on steep terrains (Jaiswal et al., 2002). The aspect map indicated that $14.38 \%$ of the study area was located on the west aspect, followed by north-west aspect (13.32\%) (Figure 7). About 36.07\% of the study area was on the south-facing aspects (south, south-east, and south-west) which are considered as risky spots for forest fires because of low humidity (Lin and Sergio, 2009).

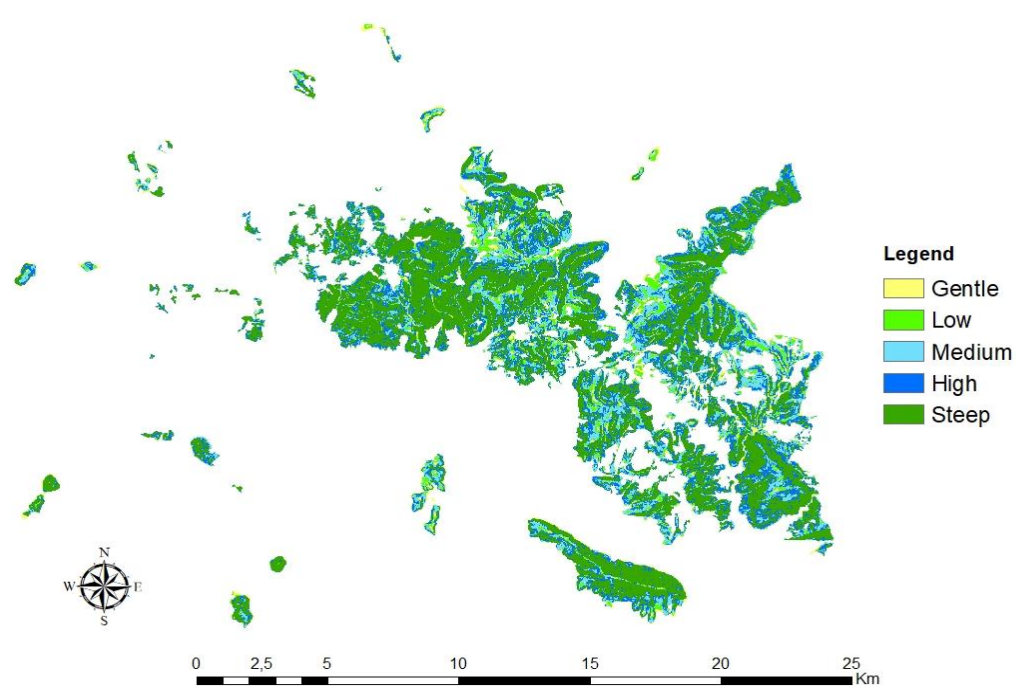

Figure 6. Ground slope map

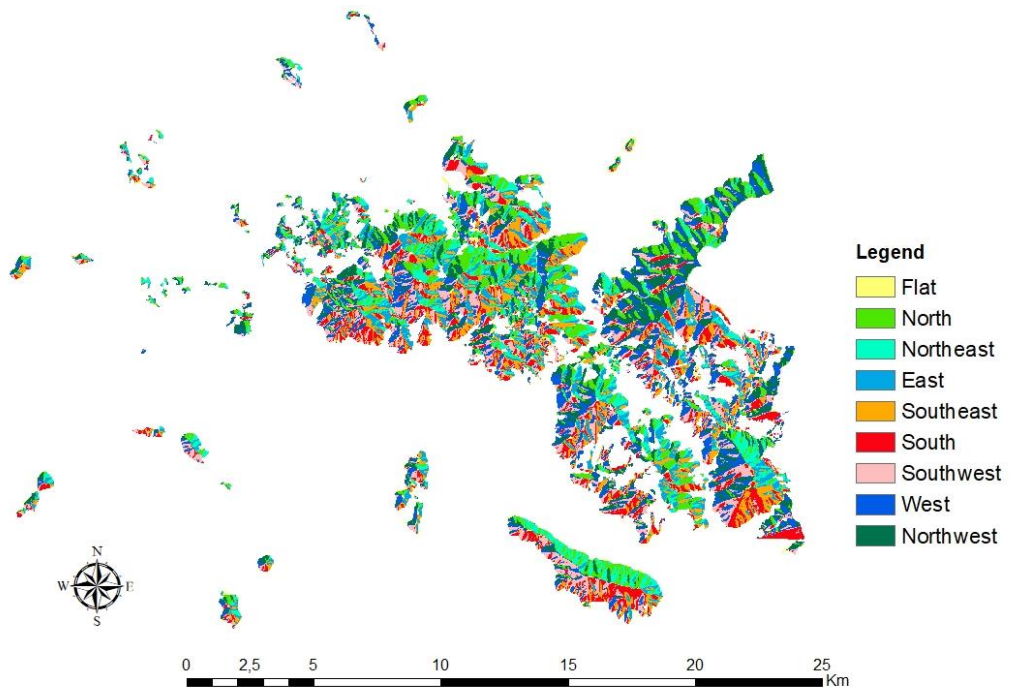

Figure 7. Aspect map

\subsubsection{Data Layers for Proximity to Roads,} Settlements, and Water Resources

Buffer zones were generated for roads, settlements, and water resources to assign forest fire risk rates for the forest areas based on their proximity to these features. Buffer zones along the road network was indicated in Figure 8 . It was found that $19.38 \%$ of the study area was within $100 \mathrm{~m}$ distance from road networks while about $46.20 \%$ was more than $400 \mathrm{~m}$ away from the roads. In terms of proximity to settlements, most of the forest area $(81.14 \%)$ was located more than $400 \mathrm{~m}$ away from the settlements (Figure 9). Only $3.89 \%$ and $4.58 \%$ of the forest area was within $100 \mathrm{~m}$ and $200 \mathrm{~m}$ distance from the settlements, respectively. Previous studies indicated that the fire risk increases as the roads and settlements get closer to the forest areas due to human factors (Jaiswal et al., 2002; Sivrikaya et al., 2014). The results indicated that $29.25 \%$ of the forest area was located within the $1000 \mathrm{~m}$ distance from the seashore, while $18.22 \%$ was located more than $4000 \mathrm{~m}$ away from the seashore (Figure 10). The distance between forest area and water resources is important since firefighting teams can access to water in short time if forest areas are close to the water resources (Çanakçığlu, 1993). 


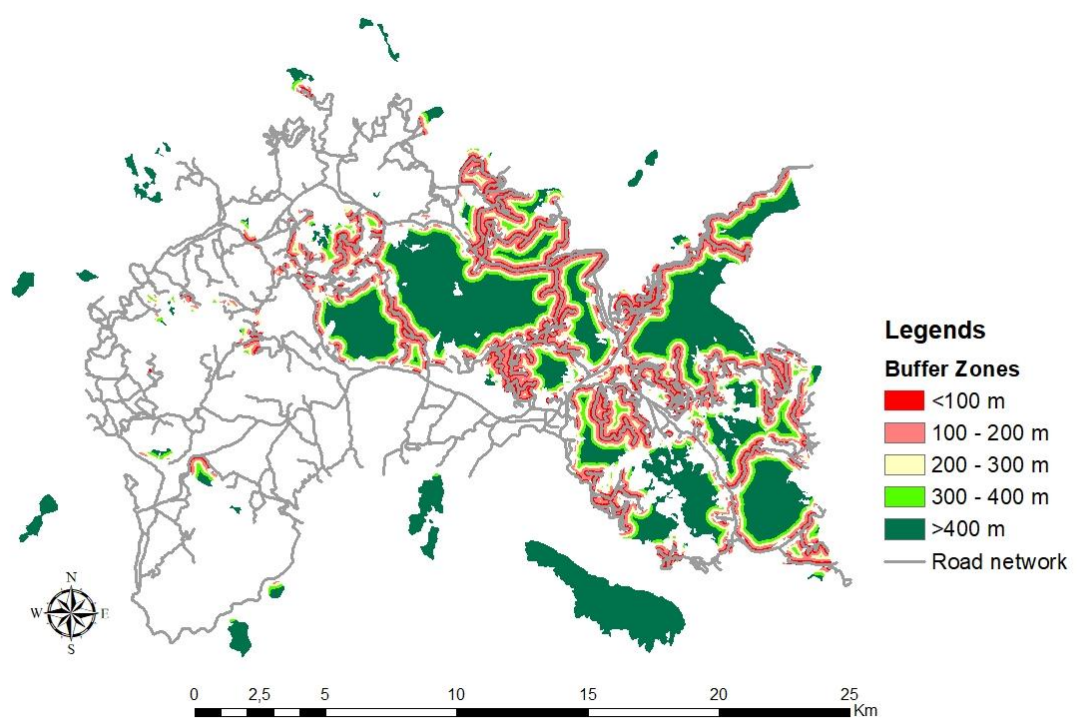

Figure 8. Buffer zones along the road network

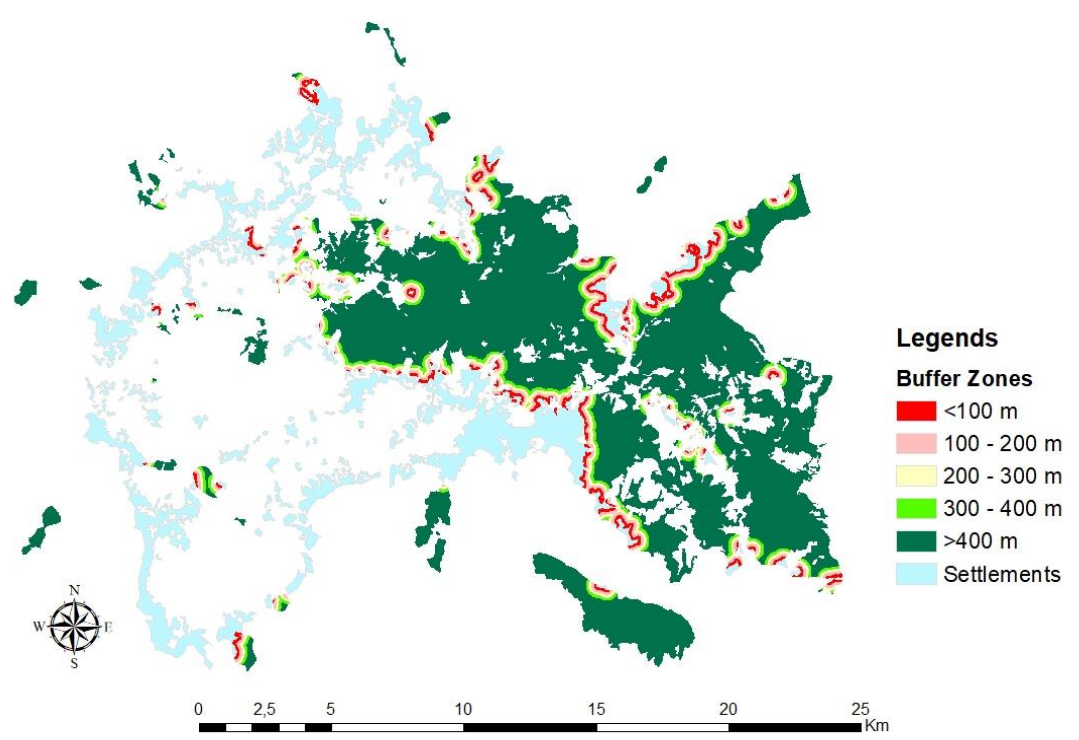

Figure 9. Buffer zones around the settlements

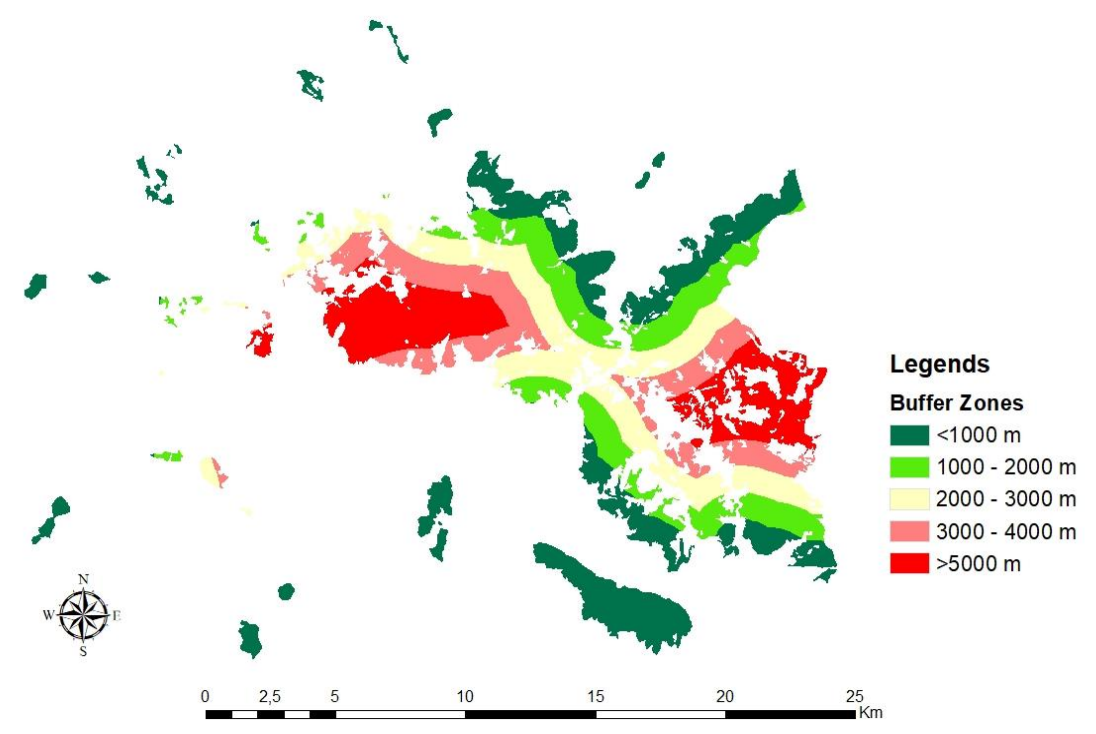

Figure 10. Buffer zones for the water resource 


\subsubsection{Previous Forest Fires Data Layers}

The map of the previous forest fires was generated based on the fire information obtained from Milas FED (Figure 11). Table 5 indicates the various information about forest fires that damaged more than one hectare of forest land in last five years (2014-2018). It was found that the fire occurred in the Component \#228 damaged the largest forest land (13.5 ha) in the study area.

Table 5. The information about previous fires in Bodrum FEC (2014-2018) (Anonymous 1)

\begin{tabular}{cccc}
\hline No & Compartments & Fire Date & Fire Damaged Area (ha) \\
\hline 1 & 144 & 7.07 .2014 & 1.00 \\
2 & 148 & 7.09 .2015 & 1.00 \\
3 & 228 & 20.04 .2016 & 13.50 \\
4 & 146 & 28.07 .2016 & 1.50 \\
5 & 181 & 22.07 .2016 & 2.00 \\
6 & 143 & 1.07 .2017 & 1.50 \\
7 & 89 & 6.07 .2018 & 2.00 \\
\hline
\end{tabular}

\subsection{AHP Results}

Based on the AHP results, the pure Brutian pine stands had the highest weighted values of potential fires risks, followed by mixed coniferous stands and Aleppo pine stands (Table 6). Date palm and degraded species had the lowest weighted values. In a similar study conducted by Akay and Erdoğan (2017), it was reported that the highest fire risk rate was in the coniferous forest, while the Oak stand and other deciduous stands had the lowest fire risk. According to the weighted values of crown closure shown in Table 7 , stands with dense closure had the highest weighted values, followed by moderate closure (Bilgili, 2003). In terms of tree stages, the weighted values of middle-aged and young stages had the highest values, while overmature stage had the lowest (Table 8).
Table 6. The weighted values of tree species

\begin{tabular}{lc}
\hline Tree Species & Weighted Values \\
Compositions & \\
\hline Brutian pine & 0,18 \\
Maquis & 0,14 \\
Degraded species & 0,12 \\
Date palm & 0,10 \\
Brutian pine, Aleppo Pine & 0,16 \\
Aleppo Pine & 0,16 \\
Stone pine & 0,14 \\
\hline
\end{tabular}

Table 7. The weighted values of crown closure

\begin{tabular}{lc}
\hline Crown losures & Weighted Values \\
\hline Bare-land & 0.09 \\
Sparse & 0.18 \\
Moderate & 0.32 \\
Dense & 0.41 \\
\hline
\end{tabular}

Table 8. The weighted values of tree stages

\begin{tabular}{lc}
\hline Tree Stages & Weighted Values \\
\hline Young & 0.27 \\
Middle-aged & 0.31 \\
Maturing & 0.23 \\
Mature & 0.12 \\
Over mature & 0.04 \\
\hline
\end{tabular}

The weighted values of ground slope indicated that the steep slope had the highest weighted values, followed by high slope areas (Table 9). In terms of aspect, south and southwest aspects had the highest weighted values, while north aspect and flat areas had the lowest (Table 10). The weighted values of buffer zones generated for roads, settlements, and water resources were indicated in Table 11-13. It was found that the weighted values of buffer zones for roads and settlements increased as the distance between these features and forest area decreased. On the other hand, the weighted values of buffer zones for water resources increased as the distance between water resources and forest area increased.

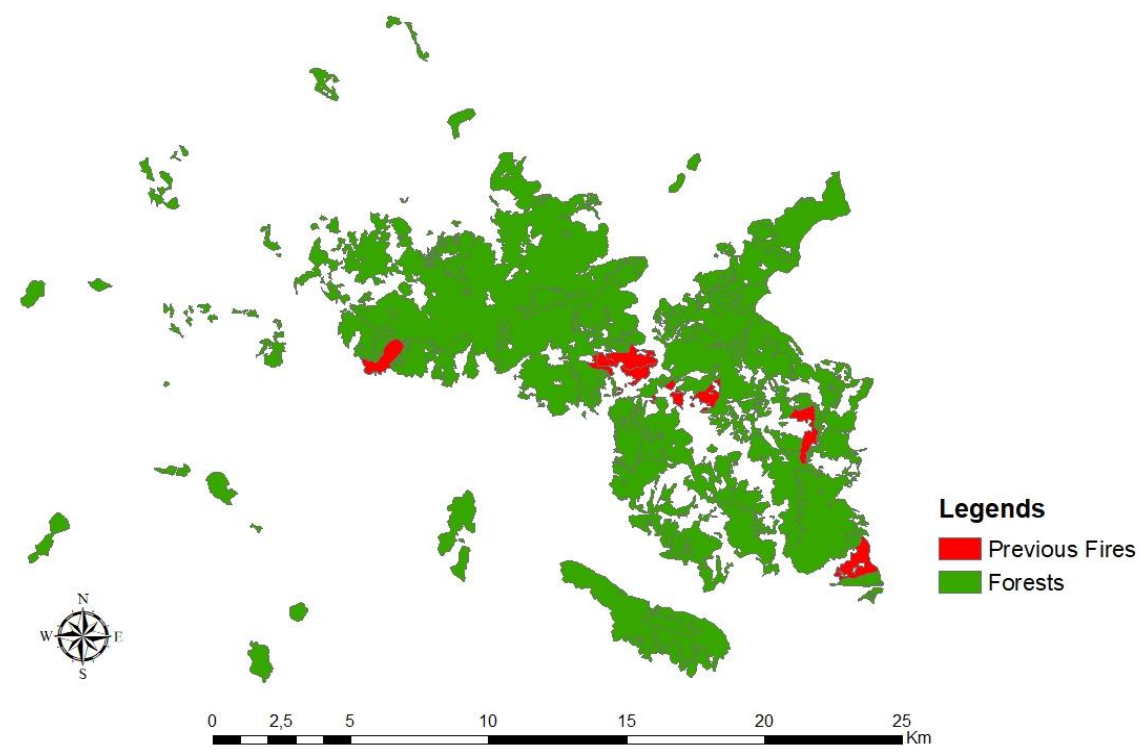

Figure 11. The map of previous fires in Bodrum FEC (2014-2018) 
Table 9. The weighted values of slopes

\begin{tabular}{lc}
\hline Slope Classes & Weighted Values \\
\hline Gentle & 0.04 \\
Low & 0.12 \\
Medium & 0.20 \\
High & 0.28 \\
Steep & 0.36 \\
\hline
\end{tabular}

Table 10. The weighted values of the aspects

\begin{tabular}{cc}
\hline Aspects & Weighted Values \\
\hline Flat & 0.05 \\
N & 0.05 \\
NE & 0.09 \\
E & 0.09 \\
SE & 0.14 \\
S & 0.20 \\
SW & 0.20 \\
W & 0.09 \\
NW & 0.09
\end{tabular}

Table 11. The weighted values of buffer zones for roads

\begin{tabular}{lc}
\hline Distance to roads & Weighted Values \\
\hline$<100 \mathrm{~m}$ & 0.39 \\
$100-200 \mathrm{~m}$ & 0.30 \\
$200-300 \mathrm{~m}$ & 0.17 \\
$300-400 \mathrm{~m}$ & 0.09 \\
$>400 \mathrm{~m}$ & 0.04 \\
\hline
\end{tabular}

Table 12. The weighted values of buffer zones for settlements

\begin{tabular}{lc}
\hline Distance to settlements & Weighted Values \\
\hline$<100 \mathrm{~m}$ & 0.36 \\
$100-200 \mathrm{~m}$ & 0.28 \\
$200-300 \mathrm{~m}$ & 0.20 \\
$300-400 \mathrm{~m}$ & 0.12 \\
$>400 \mathrm{~m}$ & 0.04 \\
\hline
\end{tabular}

Table 13. The weighted values of buffer zones for water resource

\begin{tabular}{|c|c|}
\hline $\begin{array}{l}\text { Distance to } \\
\text { water resource }\end{array}$ & Weighted Values \\
\hline$<1000 \mathrm{~m}$ & 0.04 \\
\hline $1000-2000 \mathrm{~m}$ & 0.11 \\
\hline $2000-3000 m$ & 0.22 \\
\hline $3000-4000 \mathrm{~m}$ & 0.30 \\
\hline$>4000 \mathrm{~m}$ & 0.33 \\
\hline
\end{tabular}

At the final stage, "extAhp 2.0" tool in ArcGIS as used to generate fire risk map by combining the weighted averages of the criteria (Figure 12, Table 14). It was found that the most effective criterion on forest fire was tree species, followed by tree stages and distance to water resources. Crown closure, slope and distance to settlements had the similar effect on fire risk, while distance to roads and aspect had relatively low effect on forest fire risk.

According to findings of the GIS-based AHP method, about $33.8 \%$ of the forests were within the very high and high fire risk zones (Table 15). About $43.9 \%$ of the forests were classified as very low and low fire risk areas. At the final stage, fire risk map was overlapped with the fire map indicating forest components where previous forest fires (>1.0 ha) occurred in last five years to compare the fire risk map with actual forest fire incidences in the study area. It was found that $38.32 \%$ of the areas damaged by the previous fires were categorized as high and very high fire risks zones in fire risk map, while $28.44 \%$ was moderate fire risk zones

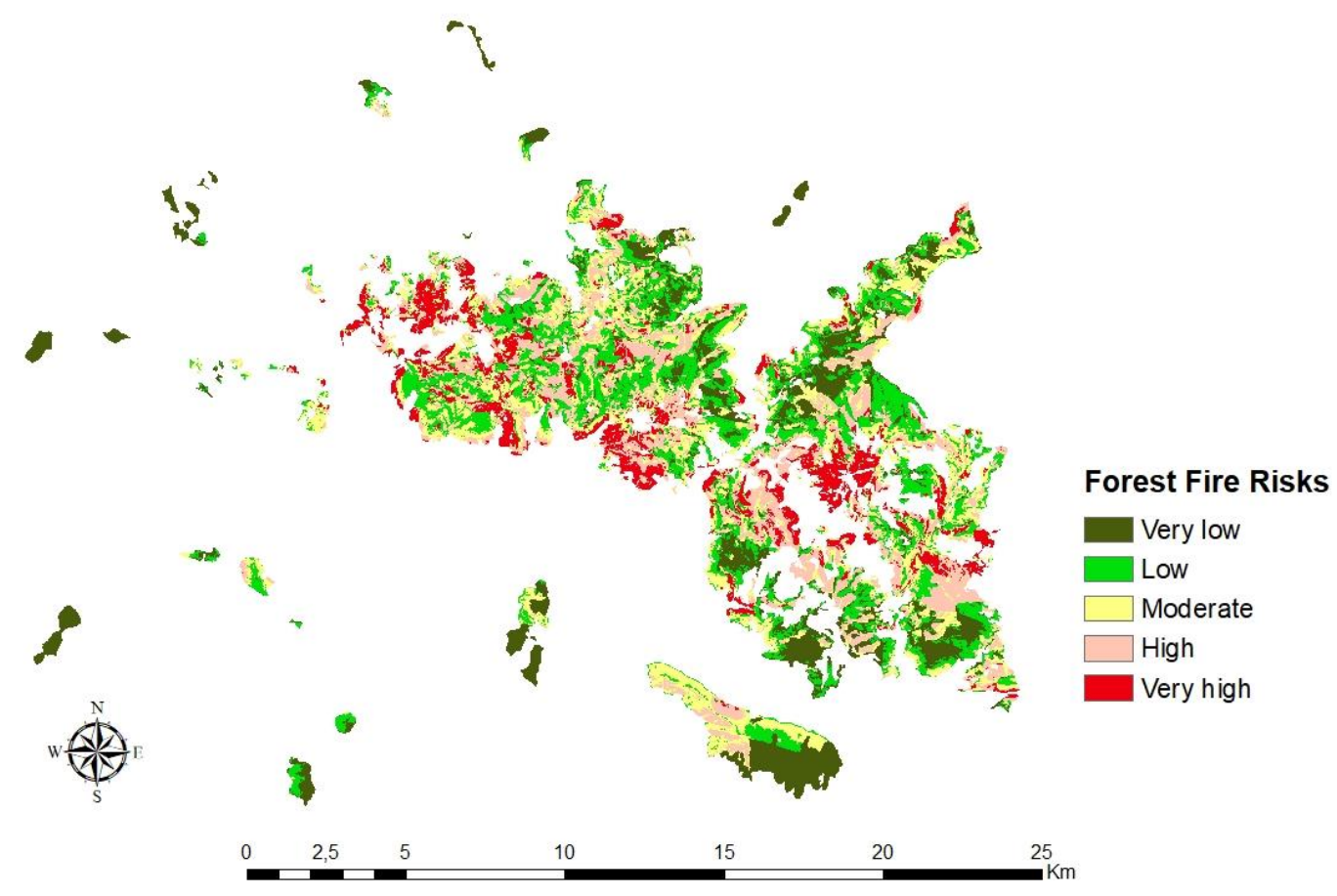

Figure 12. Forest fire risk map 
Table 14. The weighted values of criteria

\begin{tabular}{lc}
\hline Criteria & Weighted Values \\
\hline Tree species & 15.789 \\
Crown closures & 12.281 \\
Tree Stages & 14.035 \\
Slope & 12.281 \\
Aspect & 8.772 \\
Distance to roads & 10.526 \\
Distance to settlements & 12.281 \\
Distance to water resource & 14.035 \\
\hline
\end{tabular}

Table 15. The areal distribution of fire risks

\begin{tabular}{ll}
\hline Fire Risks & Area $(\%)$ \\
\hline Very low & 17.98 \\
Low & 25.93 \\
Moderate & 22.28 \\
High & 21.98 \\
Very high & 11.83 \\
\hline
\end{tabular}

\section{Conclusions}

Forest fires cause long term impacts on forest ecosystems and result in important economic losses. In

\section{References}

Akay, A.E., Erdas, O., Kanat, M., Tutus, A., 2007. PostFire Salvage Logging for Fire-Killed Brutian Pine (Pinus brutia) Trees. Journal of Applied Sciences 7(3):402-406.

Akay, A.E., Wing, G.M., Sivrikaya, F., Sakar, D. 2012. A GIS-based decision support system for determining the shortest and safest route to forest fires: a case study in Mediterranean Region of Turkey. Environmental Monitoring and Assessment, 184(3):1391-1407.

Akay, A.E., Wing, M.G., Zengin, M., Köse, O., 2017. Determination of fire-access zones along road networks in fire sensitive forests. J. For. Res., 28(3):557-564.

Akay, A.E., Erdoğan, A. 2017. GIS-based Multi-criteria Decision Analysis for Forest Fire Risk Mapping. ISPRS Annals of the Photogrammetry, Remote Sensing and Spatial Information Sciences, Volume IV-4/W4, 2017 4th International GeoAdvances Workshop, 14-15 October, Safranbolu, Karabuk, Turkey.

Anonymous 1. Forest fire data. Milas Forest Enterprise Directorate, Muğla Forest Regional Directorate, Muğla.

Başaran, M.A., Sarıbaşak, H., Çamalan, İ. 2007. Using Geographical Information System in Determination of Fire Risk and Danger Classes. Bottlenecks, Solutions, and Priorities in the Context of Functions of Forest Resources Symposium. 17-19 October, Istanbul.

Bilgili, E., 2003. Stand Development and Fire Behavior. Forest Ecol. Manag. 179:333-339. order to prevent sever damages of fires on forest resources, fire risks zones should be determined especially for the forests with high fire risk and necessary precaution measures should be taken prior to fire. In this study, GIS-based AHP method was used to generate forest fire risk map for a sample forest land classified as first degree fire sensitive area in Turkey. Tree species, crown closure, tree stages, slope, aspect, and proximity to roads, settlements, and water resources were considered as fire risk factors in the solution process. It was found that $66.75 \%$ of the areas damaged by the previous fires were categorized as moderate to high and very high fire risks zones in fire risk map developed by GIS-based AHP method. It was also found that the most effective risk factor on forest fire risk was tree species, followed by tree stages and proximity to water resources. The results revealed that GIS-based AHP method can provide fire managers with quick and effective prediction of forest fire risk zone. One of the main advantage of generating fire risk maps is to develop longterm strategic plans for fire prevention activities.

Bilici, E., 2009. A Study on the Integration of Firebreaks and Fireline with Forest Roads Networks and It's Planning and Construction (A Case Study of Gallipoly National Park) Istanbul University. Faculty of Forestry Journal Series: A 59(2):86-102.

Carmel, Y., Paz, S., Jahashan, F., Shoshany, M., 2009. Assessing fire risk using Monte Carlo simulations of fire spread. Forest Ecol. Manag. 257(1):370-377.

Çanakçioğlu, H. 1993. Forest Conservation. Istanbul University Press, Faculty of Forestry Press: Istanbul.

Demir, M., Kucukosmanoglu, A., Hasdemir, M., Ozturk, T., Acar, H.H., 2009. Assessment of forest roads and firebreaks in Turkey. African Journal of Biotechnology, 8(18):4553-4561.

Erten, E., Kurgun, V., Musaoglu, N., 2004. Forest Fire Risk Zone Mapping from Satellite Imagery and GIS a Case Study. XXth ISPRS Congress, Youth Forum, Editor(s): Orhan Altan, July 12-23, Istanbul, Turkey.

Ertuğrul, M. 2005. The Situation of Forest Fires in the World and in Turkey. ZKÜ Bartın Faculty of Forestry Journal. 7(7):43-50.

Gao, X., Fei, X., Xie, H., 2011. Forest fire risk zone evaluation based on high spatial resolution RS image in Liangyungang Huaguo Mountain Scenic Spot. IEEE International Conference on Spatial Data Mining and Geographical Knowledge Services. Fuzhou, China.

Gazzard, R., 2012. Risk Management Control Measure: Toolkit for Practitioners and Advisors. UK Vegetation Fire Risk Management. 24 p.

GDF, 2016. General Diectorate of Forest, Official Statistics,https://www.ogm.gov.tr/ekutuphane/Istatistikl er/ Ormancilik (Last axcess: 15 May 2019) 
Gülci, N. 2014. Researches on precision forestry in forest planning. Ph.D. thesis, KSU, Kahramanmaraş. 264 p.

Jaiswal, R.K., Mukherjee, S., Raju, D.K., Saxena, R., 2002. Forest fire risk zone mapping from satellite imagery and GIS. Int Journal of Applied Earth Observation and Geoinformation, 4(2002):1-10.

Küçük Ö., Bilgili, E., Durmaz, B.D., Sağlam, B., Baysal, İ. 2009. The Effect Factors on Transition from Surface Fire to Crown Fire. Kastamonu Univ., Journal of Forestry Faculty, 9(2):80-85.

Lin, J., Sergio, R., 2009. A derivation of the statistical characteristics of forest fires. Ecological Modelling 220:898-903.

Myers, J.H., Alpert, M.I., 1968. Determinant Buying Attitudes: Meaning and Measurement, Journal of Marketing, 32:13-20.

Özelkan, E. 2008 Risk Assessment Of Forest Fire By Using Satellite Data, Kaş Sample. Master Thesis.
İstanbul Technical University, Institute of Informatics, İstanbul. $71 \mathrm{~s}$.

Özşahin, E. 2014. Forest Fire Susceptibility Analysis Using GIS and AHP: The Case of Antakya Forestry Operation Directorate. Route Educational and Social Science Journal, 1(3):50-71.

Saaty, T.L., 1977. A scaling method for priorities in hierarchical structures. J Math Psychol. 15:234-281.

Sağlam, B., Bilgili, E., Durmaz, B.D., Küçük, Ö., Kadıoğulları, A.İ., Küçük, Ö., 2008. Spatio-temporal analysis of forest fire risk and danger using LANDSAT imagery, Sensors, 8:3970-3987.

Sivrikaya, F., Akay, A.E., Oğuz, H., Yenilmez, N. 2011. Mapping Forest Fire Danger Zones Using GIS: A Case Study from Kahramanmaraş. $6^{\text {th }}$ International Symposium on Ecology and Environmental Problems. 17-20 November, Antalya. 